\title{
Educational games as a strategy for teaching and learning Accounting
}

\section{Juegos didácticos como estrategia para la enseñanza y aprendizaje de la Contabilidad}

HERNÁNDEZ-HERNÁNDEZ, María Elena†** ARROYO-RUÍZ, Armando and AGUILAR-PÉREZ, Esmeralda

Tecnológico Nacional de México, Campus San Martín Texmelucan

ID $1^{\text {st }}$ Author: María Elena, Hernández-Hernández / ORC ID: 0000-0001-7172-3802, Researcher ID Thomson: O-81932018, CVU CONACYT ID: 927536

ID $1^{\text {st }}$ Co-author: Armando, Arroyo-Ruíz / ORC ID: 0000-0003-1054-1209, Researcher ID Thomson: S-5913-2018, CVU CONACYT ID: 497813

ID $2^{\text {nd }}$ Co-author: Esmeralda, Aguilar-Pérez / ORC ID: 0000-0001-6794-9630, Researcher ID Thomson: O-3376-2018, CVU CONACYT ID: 625314

DOI: $10.35429 / J E S C .2021 .14 .5 .7 .13$

Received: July 04, 2021; Accepted December 22, 2021

\begin{abstract}
Throughout the history of education, tools or mechanisms have been used for student learning, which is why educational institutions have not only focused on increasing their use, but also on updating the way and means they use to to teach. These institutions are also concerned with innovating and generating didactic tools, so that students can have the means of support that allow them to obtain new knowledge or reinforce those acquired in the classroom. In the present work, the design of a simulation kit or sets of support means is presented to carry out learning activities in an individual or group context, for the subject Introduction to Financial Accounting of the Public Accountant career of the National Technological Institute of Mexico , San Martín Texmelucan campus (ITSSMT). The methodology used was a non-experimental design, the variables in question were not manipulated, with a descriptive study to identify and design the content of the kit, a qualitative approach, having as object of study the needs of the students of the Public Accountant career ITSSMT, to which the survey for field research was applied.
\end{abstract}

Learning, Accounting, Games

\begin{abstract}
Resumen
A lo largo de la historia de la educación se han utilizado herramientas o mecanismos para el aprendizaje de los estudiantes, por lo cual las instituciones educativas no solo se han enfocado en aumentar su uso, sino también en actualizar la forma y los medios que usan para enseñar. Estas instituciones también se preocupen por innovar y generar herramientas didácticas, para que los estudiantes, puedan contar con medios de apoyo que les permitan obtener nuevos conocimientos o bien reforzara los adquiridos en el aula. En el presente trabajo se presenta el diseñó de un kit de simulación o conjuntos de medios de apoyo para realizar actividades de aprendizaje en un contexto individual o grupal, para la materia Introducción a la Contabilidad Financiera de la carrera de Contador Público del Tecnológico Nacional de México, campus San Martín Texmelucan (ITSSMT). La metodología usada fue un diseño no experimental, no se manipularon las variables en cuestión ${ }_{2}$ con un estudio descriptivo para identificar y diseñar el contenido del kit, un enfoque cualitativo, teniendo como objeto de estudio las necesidades de los estudiantes de la carrera de Contador Público del ITSSMT, a los cuales se les aplico la encuesta para la investigación de campo.
\end{abstract}

Aprendizaje, Contabilidad, Juegos

Citation: HERNÁNDEZ-HERNÁNDEZ, María Elena, ARROYO-RUÍZ, Armando and AGUILAR-PÉREZ, Esmeralda. Educational games as a strategy for teaching and learning Accounting. Journal Education Sciences. 2021. 5-14: 7-13

\footnotetext{
* Author Correspondence (e-mail: elena.hernandez@smartin.tecnm.mx)

$\dagger$ Researcher contributing as first author.
} 


\section{Introduction}

Currently the educational process is undergoing major changes, this means a real challenge for educational institutions that have to adapt to social, labor and cultural changes that involve innovative advances to be at the forefront in the teaching learning process, this situation is according to what UNESCO (2019) she considers that education is a human right for all, throughout life, and that access to instruction must be accompanied by quality, that is why it is intended to design a simulation kit of learning scenarios of the accounting discipline for the career of Public Accountant of the Tecnológico Nacional de México (TecNM), with this will support these trends that seek that students are involved and participate in the educational process, in a meaningful and collaborative way, and as it is well known the tools of education constitutes an extremely useful instrument in the planning, implementation and evaluation of learning systems.

It should be noted that Kit, according to the dictionary of the Royal Spanish Academy, is understood as "A set of products and utensils sufficient to achieve a certain purpose, which are marketed as a unit". In other words, it is a set of things that are used for a specific activity.

According to Mancilla (1999), simulation is understood as "the process of designing a model of a real system and conducting experiments with this model, with the purpose of understanding the behavior of the system and/or evaluating various strategies for the operation of the system".

On the other hand, Greco quotes Ruohomaki (2013) who defines that "a simulation is a functional representation of reality; it can be an abstract, simplified or accelerated model of a process. It pretends to have a relevant behavioral similarity with the original system".

In relation to what can be understood by Game Vigotski quoted by Baldeón (2021) describes this as "the realization of a fictitious situation extracted from reality with a certain structure that allows the transfer of a meaningful message to a student".

\section{Problem}

Due to the fact that the subject of Introduction to Financial Accounting is taught in the first semester of the Public Accountant career, in some cases the new students already have previous knowledge of this discipline, since they studied it at the Baccalaureate or High School level, Unfortunately, this is not the case in most cases, so students who do not have this knowledge face difficulties in acquiring these contents, unfortunately, sometimes not all of them are able to solve the problem and they begin to show an attitude of apathy, disinterest, and lack of motivation, or sometimes it results in desertion. In this context, we emphasize the need to apply creative, practical and specific strategies for the subject of Introduction to Financial Accounting, with which all students can acquire the knowledge presented in the classroom or reinforce those previously acquired, thus supporting the work of the teacher, while allowing him to identify areas of opportunity of the student that require attention.

\section{Objective}

The main objective is to present as a support strategy to the teaching-learning process, different didactic games to allow the students of the Public Accountant career of the ITSSMT, to acquire and strengthen the knowledge of the subject Introduction to Financial Accounting in an easy and dynamic way, in an informal environment.

\section{Methodology}

The research design was non-experimental, since it was carried out without deliberately manipulating the study variables, the natural context of those involved in the case was respected, which were the students of the Public Accountant career who were studying or had taken the subject of Introduction to Financial Accounting, in this type of research there were no conditions or stimuli to which the subjects of the study were exposed. The study was descriptive, because it sought to identify the important characteristics and needs of the participants, which should be covered with the didactic strategy, due to the above, the research was also given a qualitative approach, because the aforementioned aspects were taken into account for the design and development of the didactic games. 
On the other hand, the research was transversal, because the data collection was carried out in a single time.

The type of research used was field research, which consisted in the application of a survey to the students of the community of the Public Accounting Career, by means of a questionnaire where closed and multiple choice questions were used.

A Documentary Research was also used to know what has been done on the development of strategies in the field of accounting education.

\section{Market Study}

It was necessary to carry out a research to know if there was a didactic support in the market, either commercial or free use, that would support the teaching of the contents of the subject Introduction to Financial Accounting, the findings are shown below:

- A great variety of virtual games were found, however, they were not adaptable to the contents of the Financial Accounting program.

- Some commercial software was found, but in most cases its functions were overloaded.

- Another unfavorable aspect of these commercial systems is that most of them have a high cost.

- Physically, no didactic games were found to support the teaching-learning process of the subject in question.

According to what was investigated, it was observed that there is no free or chargeable didactic support that addresses all the topics of the subject Introduction to Financial Accounting, for example the "DOUBLE HEADING SIMULATOR", helps the learning of this accounting technique, but does not support the learning of the rest of the topics of the subject; similarly, other simulators were found that help to review the accounting entries, but only that topic.
In conclusion, we did not find a didactic tool that met our needs, which is why we decided to develop them within the Research Department with members and students of the Research Academic Body of the Public Accountant career.

\section{Survey}

In order to know the point of view of the students of the Public Accountant career of the ITSSMT about the didactic support proposed, as well as to determine the requirements that the didactic games should cover, a questionnaire was applied to 23 students. For the selection of the participants in the survey, two criteria were used: to be a current student of the Public Accountant career of the ITSSMT, that is, to be enrolled in the August - December 2020 school period, and to have taken the Introduction to Financial Accounting course.

The criteria applied for the selection of students with the intention of obtaining objective information were that they were enrolled at the time of applying the survey and that they had taken the course,

The sample was obtained from a population of 299 students enrolled in the Public Accountant career at ITSSMT, in the AugustDecember 2020 school year, from the 1st, 3rd, 5th, 7th semesters and students of professional residencies, when applying a formula to obtain the sample it was small, therefore the number was increased to 23. The field technique based on a survey was applied, by means of a questionnaire, consisting of nine open and multiple-choice questions. The answers to the most representative questions are presented below.

Did you find it difficult to learn the contents of the subject Introduction to Accounting?

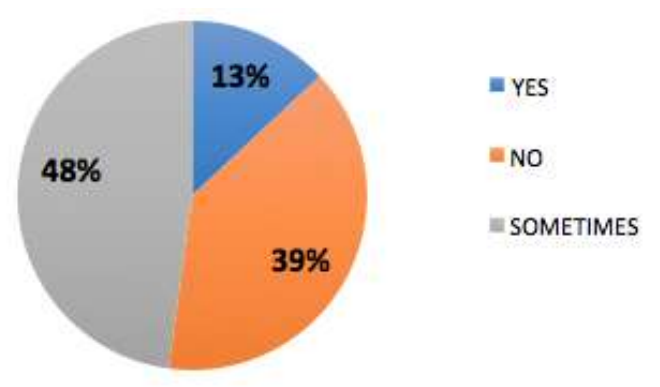

Graph 1 Analysis of the question "Difficulty in learning the contents of the Introduction to Financial Accounting" Source: Own Elaboration 
According to the opinions of the 23 respondents, $48 \%$ answered that, on some occasions it was difficult for them to learn the topics of the program Introduction to financial accounting.

Do you think it is necessary to have a didactic support to learn the contents of the subject Introduction to accounting?

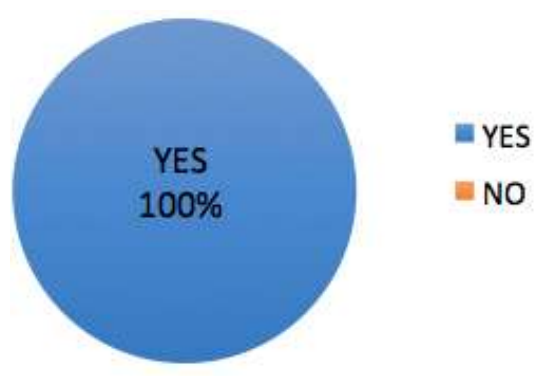

Graph 2 Analysis of the question "Need for a didactic support for the subject Introduction to financial accounting"

Source: Own Elaboration

Of the 23 respondents, $100 \%$ agree that they need a didactic support to facilitate the learning of the contents of the subject Introduction to accounting?

Do you know any didactic support to learn Accounting?

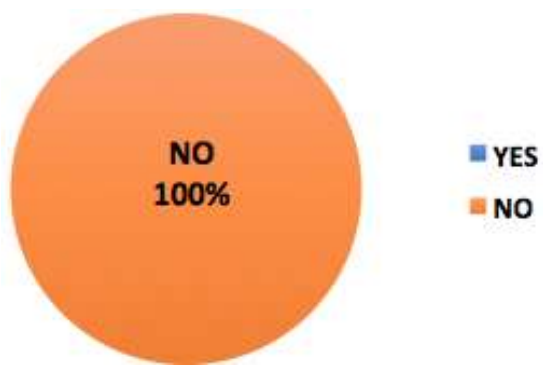

Graph 3 Analysis of the question "knowledge of any didactic support to learn accounting"

Source: Own Elaboration

It is observed that none of the 23 respondents do not know a didactic support that helps them in the learning of accounting. At the moment of collecting and making the graphs of the information obtained from the questions asked, these showed $100 \%$ favorable results, which justify the importance for the students of the Accounting career to have a didactic tool for the subject of Introduction to Financial Accounting, such as didactic games that help them acquire the knowledge of this subject in a group and informal environment, that is to say, they can learn or reinforce knowledge by playing.

\section{Proposal}

Didactic games proposed based on the syllabus of the subject Introduction to Financial Accounting, it is worth mentioning that the proposed games were selected from some already existing and known as board games, which were modified and adapted to the needs and characteristics of the students and the contents of the subject, which is why some of the rules to play were modified, as well as their physical presentation.

\section{- $\quad$ Game: Snakes and ladders}

Topic 3. Double entry theory

\section{Objectives:}

- $\quad$ Review the theory of double entry,

- $\quad$ Acquire more knowledge about crediting and debiting.

- $\quad$ Record transactions based on the rules of debiting and crediting.

\section{Specific competencies}

Record the ordinary accounting operations of the economic entity in accordance with the double entry theory and apply the debit and credit rules to the accounting of the economic entity.

\section{Instructions:}

They were developed based on the rules of the game and others were added and modified according to the topic and the learning needs of the students.

\section{Resources}

Board, cards for each question, place cards, dice, sand timer, and a timer. 


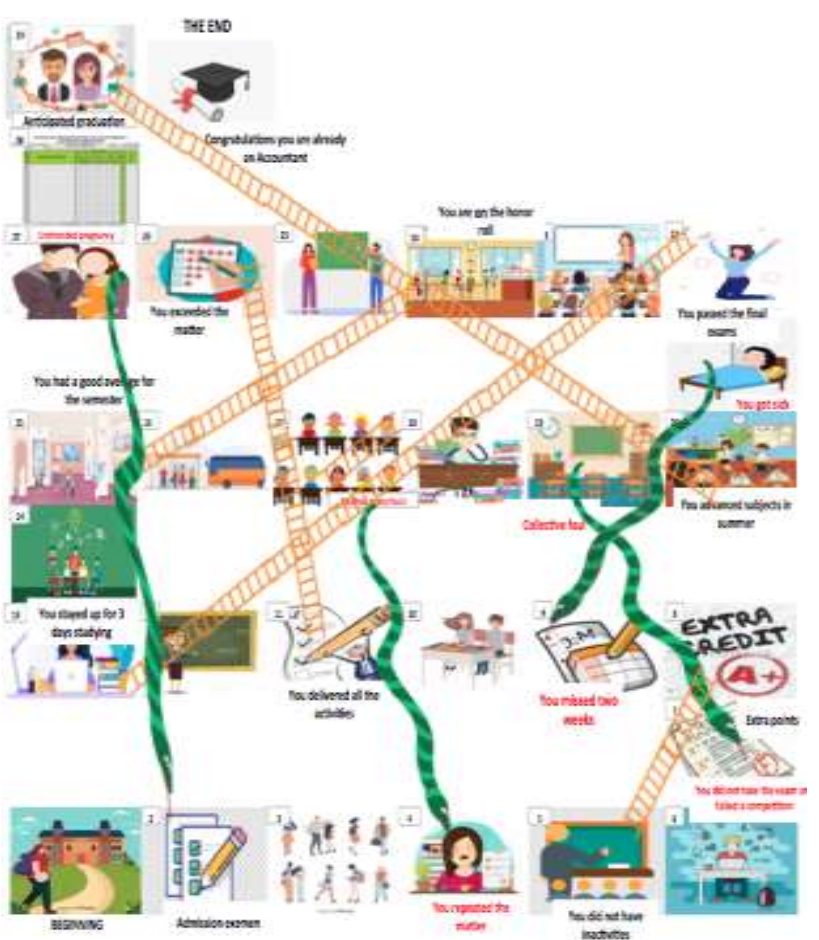

Figure 2 Snakes and ladders game Source: Own Elaboration

\section{- Game: Memorama}

Topic 2: Basic Financial Statements

\section{Objectives:}

That the student reaffirms the difference that exists in each basic financial statement, as well as the elements that integrate it.

\section{Specific competencies}

Elaboration of basic financial statements.

\section{Instructions:}

They were developed based on the rules of the game, others were added and modified according to the topic and the learning needs of the students.

\section{Resources}

Cards with the image and description according to each concept.

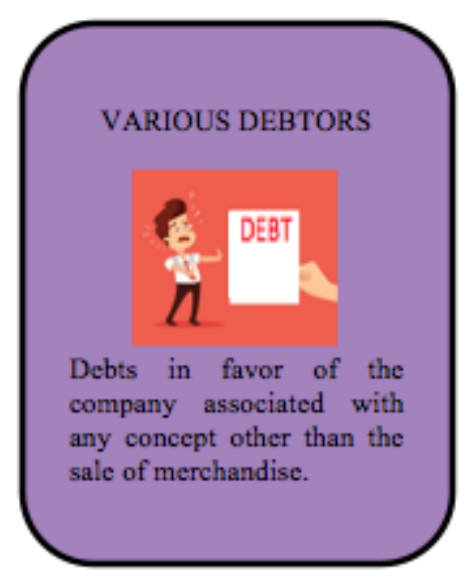

Figure 3 Memorama game card Source: Own Elaboration

\section{- Game: Headbands}

Topic: All the topics of the program Introduction to Financial Accounting.

\section{Objectives:}

To achieve that students recognize and describe the basic concepts of the syllabus of the subject Introduction to Financial Accounting found in of each card by means of key words.

\section{Specific competencies:}

Apply the accounting process for the generation of financial information with adherence to Financial Reporting Standards.

\section{Instructions:}

Developed based on the rules of the game and others were added and modified according to the subject matter and the learning needs of the students.

\section{Resources:}

20 headbands, 80 cards with concepts, 90 tokens, 10 hourglasses.
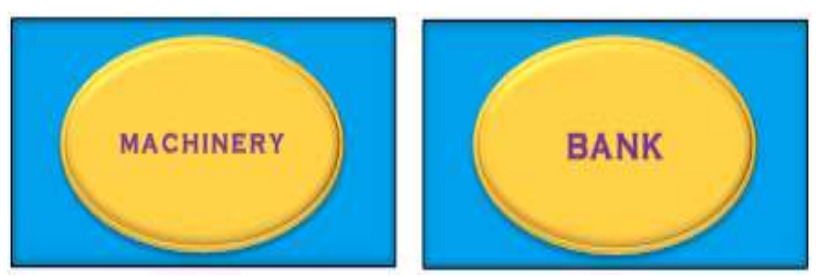

Figure 3 Headbands Game Cards Source: Own Elaboration 


\section{Game: Lottery}

Topic: 2 Basic financial statements and 3 Double entry theory.

\section{Objectives:}

- $\quad$ Review the theory of double entry,

- $\quad$ Acquire more knowledge about crediting and debiting.

- $\quad$ To record transactions based on the debit and credit rules.

- $\quad$ Have the student reaffirm the difference that exists in each basic financial statement, as well as the elements that comprise it.

\section{Specific competencies:}

Preparation of basic financial statements.

\section{Instructions:}

Developed based on the rules of the game and others were added and modified according to the topic and the learning needs of the students.

\section{Resources:}

Boards and cards with the image and description according to each concept.

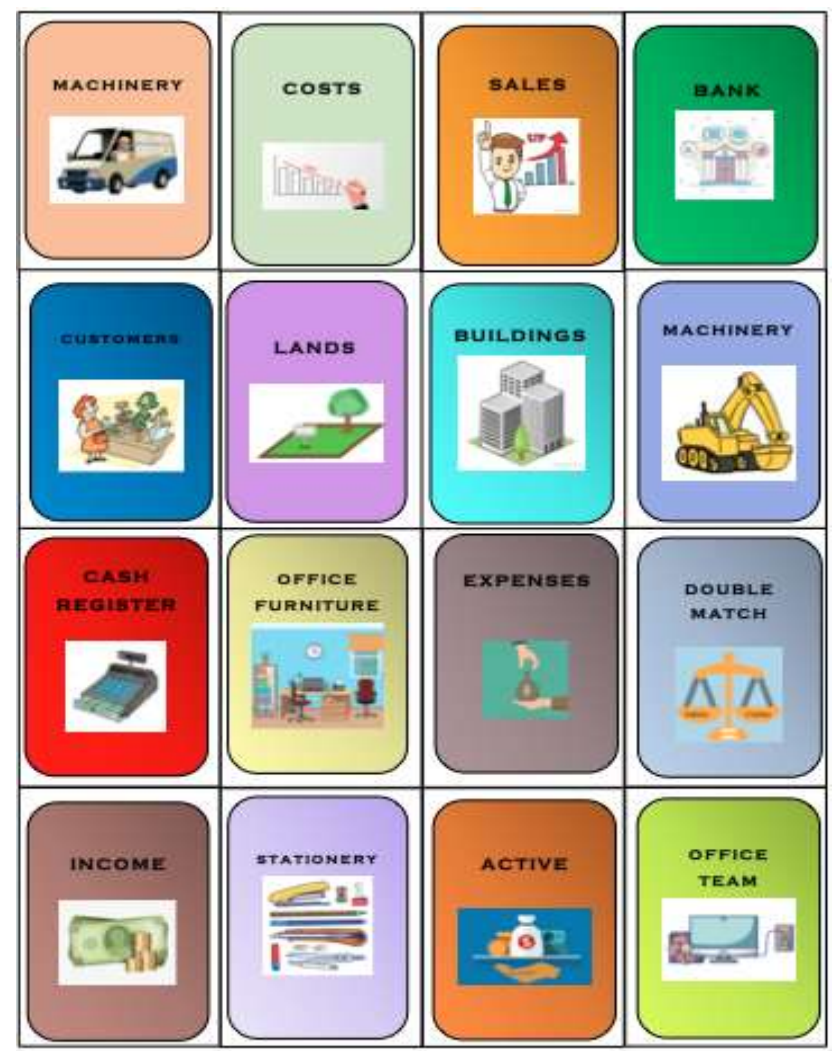

Figure 4 Loteria Game Board Source: Own Elaboration 


\section{References}

Baldeón, N. (2021). Juego de tablero contable para el aprendizaje de documentación mercantil en estudiantes de un Instituto de Educación Superior de Huancayo. Tesis para optar el grado académico de Maestro en Educación con Mención en Docencia en Educación Superior, Escuela de Posgrado, Universidad Continental, Huancayo, Perú. https://hdl.handle.net/20.500.12394/10210

Greco, M., Baldissin, N. y Nonino, F. (2013). An Exploratory Taxonomy of Business Games. Simulation \& Gaming, Vol. 44.

Mancilla, A. (1999). Simulación. Herramienta para el estudio de sistemas reales. Ingeniería y Desarrollo. Universidad de Norte.

Real Academia Española, 2020. Obtenido de: https://dle.rae.es

UNESCO (2019) La educación transforma VIDAS https://es.unesco.org/themes/education 